\title{
Factors associated with mastitis epidemiologic indexes, animal hygiene, and bulk milk bacterial concentrations in dairy herds housed on compost bedding
}

\author{
S. Fávero, F.V.R. Portilho, A.C.R. Oliveira, H. Langoni, J.C.F. Pantoja* \\ Department of Veterinary Hygiene and Public Health, Sao Paulo State University, Distrito de Rubiao Junior S/N, Botucatu, Sao Paulo 18618-970, Brazil
}

\section{A R T I C L E I N F O}

\section{Article history:}

Received 25 April 2015

Received in revised form

3 September 2015

Accepted 4 September 2015

\section{Keywords:}

Compost bedding

Mastitis

Milk quality

Cow hygiene

Moisture

\begin{abstract}
A B S T R A C T
The primary objective of this study was to identify compost bedding characteristics associated with mastitis epidemiologic indexes, cow cleanliness, and concentration of selected bacterial populations found in bulk tank milk. Secondary objectives were to monitor the occurrence of environmental mastitis outbreaks, and to describe the profile of pathogens isolated from mastitis cases of cows housed in the CBP system. Three dairies were visited monthly during 1 year. On each visit day, milk samples were collected from the bulk tank and from a sample of mammary quarters for microbiological examination. Milk samples were collected from all cases of clinical mastitis. Flank, leg, udder, and teat cleanliness were assessed using a score chart based on a 4 -point scale ( $1=$ clean to $4=$ very dirty). Bedding samples were collected to estimate concentrations of total bacteria, streptococci, and coliforms, moisture, organic matter, carbon-nitrogen ratio, $\mathrm{pH}$, and density. Mixed models were used to identify factors associated with incidence and prevalence of mastitis, and cow cleanliness. Except for farm A, on which contagious pathogens caused most cases, Escherichia coli, coagulase-negative staphylococci, and environmental streptococci were the most frequent pathogens isolated from clinical mastitis cases. Corynebacterium bovis was the most frequent pathogen isolated from subclinical cases of farms B (17.6) and C (26.0\%). Environmental pathogens were isolated from $17.2 \%, 10.1 \%$, and $14.8 \%$ of all subclinical cases of farms, A, B, and $C$, respectively. No outbreaks of environmental mastitis were observed during the course of the study. Bedding moisture, carbon-nitrogen ratio, $\mathrm{pH}$, and dry density were unconditionally associated with the incidence of environmental clinical mastitis. Nonetheless, bedding moisture remained as a sole predictor in the final model. The odds of a case of environmental clinical mastitis increased $5.7 \%$ for each one-unit increase in bedding moisture. The odds of a new case of subclinical mastitis, and of a cow having SCC $\geq 200,000$ cells/mL increased $32 \%$ and $16 \%$ for each one-unit increase in leg cleanliness score, respectively. Overall means for udder, teat, flank, and leg hygiene scores were less than 2.1 for all farms and did not vary among seasons of the year. Bedding wet density was positively associated with all cleanliness scores and bulk milk concentration of total bacteria. Results suggest that managing bedding to remain dry and loose will result in cleaner animals with decreased risk of mastitis.
\end{abstract}

(c) 2015 Elsevier B.V. All rights reserved.

\section{Introduction}

The compost bedded pack system (CBP) has been increasingly used worldwide to confine dairy cows. The CPB is characterized by a process of microbiological decomposition of an organic substrate (such as wood shavings or sawdust), to which feces and urine are constantly added by cows. Bedding is tilled twice a day to incorporate animal waste, facilitate aerobic composting, and provide a comfortable and dry surface to cows (Barberg et al., 2007a,

\footnotetext{
* Corresponding author.

E-mail address: pantoja@fmvz.unesp.br (J.C.F. Pantoja).
}

2007b; Janni et al., 2007; Black et al., 2013).

Because compost bedding is mostly organic, one of the potential hazards for udder health is the concentration of environmental mastitis pathogens. Coliforms (such as Escherichia coli and Klebsiella spp) and environmental streptococci (such as Streptococcus uberis and Streptococcus dysgalactiae) are the most prevalent pathogens causing clinical mastitis on farms that have successfully controlled contagious mastitis (Jobim et al., 2010; Lago et al., 2011; Oliveira and Ruegg, 2014). Environmental streptococci are also one of the main causes of subclinical mastitis in herds worldwide (Jobim et al., 2010; Oliveira and Ruegg, 2014).

Barberg et al. (2007a, 2007b) reported that mean bedding concentration of total bacteria was $9.1 \times 10^{6} \mathrm{cfu} / \mathrm{cc}$ for a group of $12 \mathrm{CBP}$ 
in Minnesota. Lobeck et al. (2012) reported bedding concentrations of $1.4 \times 10^{3}, 280$, and $3 \times 10^{6} \mathrm{cfu} / \mathrm{mL}$ for coliforms, Klebsiella spp, and environmental streptococci, respectively. Bedding concentration of environmental streptococci was not different between $\mathrm{CBP}$ and sand-bedded freestalls, but concentrations of coliforms and Klebsiella spp in CBP bedding were 47 and 14 times greater than those observed in naturally ventilated sand-bedded freestalls, respectively (Lobeck et al., 2012). Other environmental pathogens that might be present in compost bedding, such as Nocardia spp, Pseudomonas spp, and Prototheca spp, have been associated with herd outbreaks of clinical and subclinical mastitis, and are capable of causing chronic, untreatable mastitis (Janosi et al., 2001; Condas et al., 2013). The occurrence of such pathogens in herds housed on compost bedding has not been studied.

In this context, little research has been conducted to describe the profile of pathogens causing clinical and subclinical mastitis, to assess the risk of intramammary infections (IMI) caused by environmental pathogens, and to characterize the quality of milk produced in CBP systems. Two studies were conducted to describe longitudinal changes in bulk tank milk SCC from herds that shifted from other systems to the CBP. Barberg et al. (2007a, 2007b) observed SCC reduction in 5 of 7 herds by comparing mean monthly dairy herd improvement (DHI) somatic cell count (SCC) before (2 years) and after (1 year) the change. Likewise, Black et al. (2013) reported that mean SCC of 8 herds decreased from 411,000 cells $/ \mathrm{ml}$ (12-month mean prior to the change) to 305,000 (first year) and 275,000 cells/ml (second year) after the change. Nonetheless, a causal relationship between the use of CBP and bulk tank milk SCC should not be established solely on these data because control groups were not used for comparison.

Results of experimental studies performed to investigate the effect of housing cows in the CBP on the occurrence of mastitis have been contradictory. Astiz et al. (2014) reported that cows maintained on compost bedding during the dry period had reduced incidence of clinical mastitis in the subsequent lactation, as compared to cows housed on straw bedding. In contrast, Svennesen et al. (2014) reported a herd SCC increase of 72.000 cells $/ \mathrm{mL}$ for animals randomly allocated to a CBP of high moisture content (65-70\%, bedded with chopped roots, wood shavings and garden organic residues), as compared to a group of cows that remained in a sand-bedded freestall. These conflicting results suggest that compost bedding characteristics play a major role in minimizing the risk of IMI.

Among bedding-related indicators of animal health, cow cleanliness has been universally used as an indicator of udder health. Results of cross-sectional studies conducted at the herd level have consistently demonstrated that herds in which most cows were scored "clean" were more likely to have less bulk tank milk SCC than herds in which most cows were scored "dirty" (Barkema et al., 1998; Ellis et al., 2007; Dufour et al., 2011). Although results of North American studies (Barberg et al. 2007a, 2007b; Shane et al., 2010; Black et al., 2013) have demonstrated that cows housed in the CBP are maintained in good hygienic conditions (comparable to those found in well managed sandbedded freestalls), researchers reported difficulties maintaining clean cows during humid and rainy weather (Lobeck et al., 2011). In those studies, visual observations suggested that cow cleanliness was dependent on bedding moisture (especially during winter) and density of the CBP, but these associations have not been scientifically demonstrated. Identification of CBP bedding factors associated with animal hygiene is integral for developing management practices towards maintaining clean cows and minimizing the risk of mastitis.

The primary objective of this longitudinal study was to identify compost bedding characteristics associated with mastitis epidemiologic indexes, cow cleanliness, and concentration of selected bacterial populations found in bulk tank milk. Secondary objectives were to monitor the occurrence of environmental mastitis outbreaks, and to describe the profile of pathogens isolated from mastitis cases of cows housed in the CBP system.

\section{Materials and methods}

\subsection{Farm selection and sampling strategy}

At the beginning of the study, all known CBP dairies in Sao Paulo state, Brazil $(N=4)$ were contacted and agreed to participate in the study. Of these dairies, one was not used for the study due to the distance from the university ( $>300 \mathrm{~km}$ ). Other inclusion criteria were adoption of compost bedding as sole system to confine lactating cows, participation in a monthly DHI testing program, and willingness to comply with the study protocol.

Initially farms were visited to explain the study protocol and provide training for collection of bedding and milk samples. Farms were then visited monthly between May 2013 and June 2014 for data collection and sampling.

\subsection{Farm and animal characteristics}

Farm and animal characteristics are given in detail elsewhere (Favero et al., 2015). In brief, Farm A had 33 lactating Holsteins that were milked twice a day. The CBP was approximately 6 months old at the beginning of the study and consisted of an area of $290 \mathrm{~m}^{2}$ $\left(11 \mathrm{~m}^{2} / \mathrm{cow}\right)$ bedded with peanut shells. Seventy $\mathrm{m}^{3}$ of new bedding were added monthly to the CBP. Bedding was tilled twice a day between milkings using a deep cultivator. Fans were installed throughout the barn over the bedding area. Cows were machinemilked on the concrete feeding alley and milk was stored within a bulk tank. The milking routine consisted of examination of the first milk streams on a strip cup, pre-milking teat disinfection with a chlorine-based solution, drying of teats with single paper towels, and use of a barrier post-milking teat dip (1\% iodine).

Farm B had 53 lactating Holsteins that were milked twice a day. The CBP was approximately 2 months old at the beginning of the study and was bedded with sawdust. The CBP area on farm B was $1000 \mathrm{~m}^{2}\left(19 \mathrm{~m}^{2} / \mathrm{cow}\right)$ and $34 \mathrm{~m}^{3}$ of new bedding were added monthly. Bedding was tilled twice a day between milkings using a deep cultivator, and a rototiller was used occasionally to loose the material and decrease particle size. Bedding was entirely replaced once, during the last month of the study. No fans were installed over the bedding area. Cows were machine-milked in a Herringbone pit parlor and milk was stored in a bulk tank. The milking routine consisted of examination of the first milk streams on a streak cup, pre-milking teat disinfection with sodium hypochlorite, drying of teats with single paper towels, and use of a barrier acid lactic-based post-milking teat dip.

Farm $C$ had 145 Simmental lactating cows that remained on a bedding area of $1580 \mathrm{~m}^{2}\left(12 \mathrm{~m}^{2} / \mathrm{cow}\right)$. The CBP was approximately 2 months old at the beginning of the study. Wood shavings were used as bedding material and $38 \mathrm{~m}^{3}$ of new bedding were added monthly to the CBP. Bedding was tilled twice a day between milkings using a deep cultivator and a rototiller was used twice a week to further decrease particle size. Bedding was entirely replaced once, during the first month of the study. Fans were installed over the bedding area at the 7th month of the study. Cows were machine-milked in a Herringbone pit parlor and milk was stored in a bulk tank. The milking routine consisted of examination of the first milk streams on a streak cup, pre-milking teat disinfection with iodine $0.5 \%$, drying of teats with single paper towels, and use of a lactic acid-based post-milking teat dip.

Although the study was observational, farmers asked for milk 
quality advice during the study. Therefore, at the beginning of the study, the authors recommended management practices based on the NMC's 10-point mastitis control plan (NMC; Verona, WI). Farms complied with proposed changes at different levels, according to their interest in improving milk quality.

\subsection{Milk sampling}

On each visit day, cows whose most recent DHI composite SCC was $>200.000$ cells $/ \mathrm{mL}$ were tested with the California Mastitis Test (CMT) for identification of possibly infected quarters. Aseptic milk samples were collected from a random sample of CMT-positive quarters ( 1 quarter per cow) for microbiological examination. Sampling of $50 \%, 50 \%$, and $30 \%$ of the high SCC cows was attempted on farms $A$ ( $<100$ cows), $B$ ( $<100$ cows), and $C(>100$ cows), respectively. The number of cows sampled was calculated based on herd size, to provide a representative sample of mastitis pathogens, without disrupting milking routines.

Bulk tank milk samples were collected on each visit day using sterile uterine infusion pipettes attached to $60-\mathrm{mL}$ syringes, after milk was agitated for at least $5 \mathrm{~min}$. All milk samples were refrigerated and frozen on the same day.

Aseptic quarter milk samples were also collected and frozen by trained farm personnel before treatment (or at detection for cases that were not treated) from all cases of clinical mastitis that occurred during the study. Clinical mastitis was identified using a strip cup and was defined as the presence of milk abnormalities such as flakes, pus, and changes in color. Severity of the cases was recorded as mild, moderate, or severe, according to the scale proposed by Wenz et al. (2001).

\subsection{Cow cleanliness assessment}

On each visit day, cleanliness of the flank, leg, and udder was assessed before milking (within the CBP area) by use of a score chart based on a 4-point scale ranging from 1 (clean) to 4 (very dirty) (Canadian Bovine Mastitis Research Network; Montreal, Canada). All lactating cows were scored on farms A and B $(<100$ cows), and $50 \%$ of the cows were scored on farm $C$ ( $>100$ cows), according to chart instructions.

On each visit day, teat swabs were collected during milking (before any milking procedure was performed) to assess teat cleanliness and estimate the population of total bacteria, coliforms, and streptococci on teat skin. Eight sterile gauze pads were placed into a sterile $50-\mathrm{mL}$ plastic container and $25 \mathrm{~mL}$ of $0.1 \%$ peptone water were added to moisten swabs and preserve bacteria. To collect swabs, teats were scrubbed with 1 circular movement around the teat barrel, finishing with a pinch of the teat end. For all farms, swabs were collected from a random sample of 30 cows ( 1 teat per cow), alternating the swabbed teat between cows in a clockwise manner. Swabs were returned to sterile containers and refrigerated until processing. Teat cleanliness was assessed by use of a score card based on a 4-point scale (GEA Farm Technologies, Inc.; Naperville, IL, USA). For each visit, results of each cleanliness score type were reported as herd weighted mean score (weight $=1,2,3$, or 4 ).

\subsection{Bedding sampling}

Bedding samples were collected biweekly by trained farm personnel, as described by Barberg et al. (2007a, 2007b). For the present study, a subset of monthly bedding samples collected on the visit days was used for analysis. In brief, the bedding area of each farm was divided into 12 equal squares, from which 1 sample was collected from the superficial and deep $(20 \mathrm{~cm})$ layers. All samples from each layer were mixed to create a composite sample for each layer, which were used to determine bedding bacterial concentrations. The composite samples of each layer were then mixed to create a composite sample that was used to determine bedding physical-chemical characteristics (moisture (\%), organic matter (\%), carbon-nitrogen ratio, $\mathrm{pH}$, and wet and dry densities $\left.\left(\mathrm{kg} / \mathrm{m}^{3}\right)\right)$.

\subsection{Microbiological examination of milk, bedding, and teat swabs}

Bedding samples were processed in the Sao Paulo State University's Mastitis Research Laboratory. Microbiological analyses of bedding was performed by adding $90 \mathrm{~mL}$ of $0.1 \%$ peptone water to $10 \mathrm{~g}$ of bedding (Zdanowicz et al., 2004). Samples were mixed for 1 minute and let settle for $2 \mathrm{~min}$. One-hundred $\mu \mathrm{L}$ of diluted samples $\left(10^{-2}-10^{-5}\right)$ were spread onto blood agar, MacConkey, and Edward's medium and incubated for $24 \mathrm{~h}$ to determine the concentration ( $\log 10 \mathrm{cfu} / \mathrm{g}$ of bedding) of total bacteria, coliforms and streptococci, respectively. Bedding samples were sent to the Sao Paulo State University's Soil Science Laboratory for determination of physical-chemical characteristics.

Milk samples from clinical and subclinical cases were processed in the Sao Paulo State University's Mastitis Research Laboratory and cultivated according to the NMC recommendations (NMC, 1999). In brief, $10 \mu \mathrm{L}$ of each milk sample were streaked onto blood agar and McConkey plates. Plates were incubated at $37^{\circ} \mathrm{C}$ and read at 24,48 , and $72 \mathrm{~h}$. Mastitis pathogens were diagnosed based on morphology (Gram staining) and biochemical reactions. Staphylococcus aureus was differentiated from other staphylococci by means of mannitol and tube coagulase reactions. Streptococcus spp were identified with the Christie-Atkins-Munch-Petersen (CAMP) test, esculin, and bile-esculin reactions. Gram-negative bacteria were identified by growth on McConkeky agar, lactose production, and reactions on MIO (motility-indole-ornithine), citrate, and TSI (triple sugar iron) agar slants.

An intramammary infection was defined as the presence of 3 or more colonies of the same type. Non-significant growth $(<3$ colonies of the same type) was considered negative for analysis and samples were contaminated when there were 3 or more colony types on plates. Bulk tank milk concentrations of total bacteria, coliforms, and streptococci were estimated by inoculating $100 \mu \mathrm{L}$ of milk (undiluted to $10^{-4}$ ) onto Blood agar, McConkey, and Edward's medium, respectively. Plates were incubated at $37^{\circ} \mathrm{C}$ and read at $24 \mathrm{~h}$. Results were expressed as $\log 10 \mathrm{cfu} / \mathrm{mL}$.

Upon arrival to the laboratory, teat swabs were placed into a sterile plastic container and weighted. Twice as much peptone water was added to the plastic bag, which was stomached for $2 \mathrm{~min}$. One $\mathrm{mL}$ of the solution was then used to create serial dilutions $\left(10^{-1}-10^{-3}\right)$. Concentrations of total bacteria, coliforms, and streptococci were estimated by inoculating $100 \mu \mathrm{L}$ of the swab solutions onto Blood agar, McConkey, and Edward's medium, respectively, as previously described. Results were expressed as $\log 10 \mathrm{cfu} / \mathrm{mL}$ of solution.

\subsection{Statistical analysis}

\subsubsection{Definitions}

Monthly DHI SCC was used to estimate the presence of IMI at the cow level (suspect infection). The SCC threshold used by the DHI association to identify a suspect subclinical infection was 200,000 cells/mL. Prevalence of subclinical mastitis was defined as the percentage of cows with SCC $>200,000$ cells $/ \mathrm{mL}$ at a given test day. Incidence of subclinical mastitis was defined as the number of cows whose SCC increased from $<200,000$ to $\geq 200,000$ cells $/ \mathrm{mL}$ on 2 consecutive test days, divided by the number of cows whose SCC was $<200,000$ cells/mL on the previous test day. 
Table 1

Results of microbiological examination of milk, by farm and mastitis type.

\begin{tabular}{|c|c|c|c|c|c|c|c|}
\hline \multirow[t]{2}{*}{ Mastitis type } & \multirow[t]{2}{*}{ Result } & \multicolumn{2}{|c|}{ Farm B } & \multicolumn{2}{|c|}{ Farm A } & \multicolumn{2}{|c|}{ Farm C } \\
\hline & & $N$ & $\%$ & $N$ & $\%$ & $N$ & $\%$ \\
\hline \multirow[t]{20}{*}{ Clinical } & Bacillus spp & & & & & 1 & 1.4 \\
\hline & Citrobacter spp & 1 & 1.7 & & & 2 & 2.8 \\
\hline & $\begin{array}{l}\text { Coagulase-negative } \\
\text { staphylococci }\end{array}$ & 7 & 11.7 & 1 & 2.2 & 6 & 8.5 \\
\hline & Corynebacterium bovis & 3 & 5.0 & 4 & 8.7 & 7 & 9.9 \\
\hline & Enterobacter spp & 2 & 3.3 & 1 & 2.2 & 1 & 1.4 \\
\hline & Enterococcus spp & & & 2 & 4.3 & 1 & 1.4 \\
\hline & Escherichia coli & 5 & 8.3 & & & 12 & 16.9 \\
\hline & Gram-negative rods & 3 & 5.0 & & & 3 & 4.2 \\
\hline & Klebsiella spp & 3 & 5.0 & 4 & 3.1 & 1 & 1.4 \\
\hline & Yeast & 3 & 5.0 & & & & \\
\hline & Serratia spp & 1 & 1.7 & & & & \\
\hline & Staphylococcus aureus & & & & & 5 & 7.0 \\
\hline & Streptococcus agalactiae & 1 & 1.7 & 20 & 43.5 & & \\
\hline & Streptococcus dysgalactiae & 2 & 3.3 & & & & \\
\hline & Streptococcus spp & & & 1 & 2.2 & 3 & 4.2 \\
\hline & Streptococcus uberis & 1 & 1.7 & & & & \\
\hline & Trueperella pyogenes & 1 & 1.7 & & & & \\
\hline & No growth & 25 & 41.7 & 10 & 21.7 & 24 & 33.8 \\
\hline & Contaminated & 2 & 3.3 & 7 & 15.2 & 5 & 7.0 \\
\hline & Total & 60 & 100 & 50 & 103 & 71 & 100 \\
\hline \multirow[t]{20}{*}{ Subclinical } & Citrobacter spp & 2 & 0.7 & & & & \\
\hline & $\begin{array}{l}\text { Coagulase-negative } \\
\text { staphylococci }\end{array}$ & 30 & 10.8 & 9 & 7.0 & 23 & 7.6 \\
\hline & Corynebacterium bovis & 49 & 17.6 & 16 & 12.5 & 79 & 26.0 \\
\hline & Enterobacter spp & 1 & 0.4 & & & & \\
\hline & Enterococcus spp & 3 & 1.1 & 1 & 0.8 & 10 & 3.3 \\
\hline & Escherichia coli & & & & & 2 & 0.7 \\
\hline & Gram-negative rods & 3 & 1.1 & & & & \\
\hline & Klebsiella spp & 3 & 1.1 & 4 & 3.1 & 4 & 1.3 \\
\hline & Yeast & 1 & 0.4 & & & 4 & 1.3 \\
\hline & Prototheca spp & & & & & 1 & 0.3 \\
\hline & Pseudomonas spp & 2 & 0.7 & 1 & 0.8 & & \\
\hline & Serratia spp & 1 & 0.4 & & & 1 & 0.3 \\
\hline & Staphylococcus aureus & 3 & 1.1 & & & 36 & 11.8 \\
\hline & Streptococcus agalactiae & 6 & 2.2 & 29 & 22.7 & & \\
\hline & Streptococcus dysgalactiae & 4 & 1.4 & 1 & 0.8 & 7 & 2.3 \\
\hline & Streptococcus spp & 8 & 2.9 & 11 & 8.6 & 13 & 4.3 \\
\hline & Streptococcus uberis & & & 4 & 3.1 & 3 & 1.0 \\
\hline & No growth & 160 & 57.6 & 42 & 32.8 & 106 & 34.9 \\
\hline & Contaminated & 2 & 0.7 & 10 & 7.8 & 15 & 4.9 \\
\hline & Total & 278 & 100 & 128 & 100 & 304 & 100 \\
\hline
\end{tabular}

Incidence of clinical mastitis was defined as the number of cows who experienced mastitis during a one-month period, divided by the number of lactating cows in the herd on the DHI test day. For cows that experienced repeated episodes of clinical mastitis (regardless of the quarter), only cases that occurred after
14 days from a previous case were considered new.

Mastitis pathogens isolated during the study (Table 1) were also grouped as environmental (coliforms, Bacillus spp, Lactosenegative Gram-negative rods, environmental streptococci, yeast, Prototheca spp, Trueperella pyogenes, and Pseudomonas spp), contagious (Streptococcus agalactiae, S. aureus, and Corynebacterium bovis), and opportunistic (Coagulase-negative staphylococci).

Bedding age was defined as the time interval between the last bedding total replacement and a given visit day. Bedding age was categorized into 1 ( $\leq 4), 2$ (5-8), and 3 ( $\geq 9$ months old).

\subsubsection{Analytical procedures}

Initially the distribution of variables was analyzed to assess normality. All bacterial counts (bedding, milk, and teat swabs) were not normally distributed and therefore transformed to a $\log 10$ scale for analysis. Descriptive statistics were produced to generate reference values for the variables studied. Explanatory variables were mastitis epidemiologic indexes (incidence of clinical mastitis, incidence of environmental clinical mastitis, incidence of subclinical mastitis, and prevalence of subclinical mastitis) and cow cleanliness scores (udder, teat, flank, and leg). Explanatory variables for mastitis epidemiologic indexes were teat, udder, leg, and flank cleanliness, season (summer, fall, winter, and spring), bedding age, and all bedding characteristics presented in Table 2. Explanatory variables for cleanliness scores were season, bedding age, and all bedding characteristics presented in Table 2. Preliminarily, bivariate analysis was used to identify unconditional associations between each explanatory variable and study outcomes. Variables associated with a given outcome at a significance level of 0.15 , and interaction terms between farm and explanatory variables were included in a stepwise model selection procedure to select final models.

All epidemiologic indexes were initially modeled as binomial outcomes by use of logistic regression, according to the following structure (Littell et al., 2006; PROC GLIMMIX, SAS Institute, 2011):

$\operatorname{logit}(Y)=\alpha+\beta_{i}\left(X_{i}\right)+\delta_{j}$

where $Y$ was prevalence or incidence of mastitis, $\alpha$ was the intercept, $\beta_{\mathrm{i}}\left(X_{i}\right)$ was the $i$ th coefficient for the $i$ th explanatory variable, and $\delta_{j}$ was a random term to model repeated measurements within the $j$ th farm. When overdispersion was detected, a negative binomial distribution was used for modeling (Palta, 2003), according to the following structure:

$\log (Y)=\alpha+\beta_{i}\left(X_{i}\right)+$ offset $+\delta_{j}$

were $Y$ was the number of new mastitis cases in a one-month period, or number of cases at a given test day, $\alpha$ was the intercept, $\beta_{i}$ $\left(X_{i}\right)$ was the $i$ th coefficient for the $i$ th explanatory variable, $\delta_{j}$ was a

Table 2

Descriptive statistics for bedding characteristics, by farm.

\begin{tabular}{|c|c|c|c|c|c|c|c|c|c|c|c|c|c|c|c|}
\hline \multirow[t]{2}{*}{ Bedding variable } & \multicolumn{5}{|c|}{ Farm A } & \multicolumn{5}{|c|}{ Farm B } & \multicolumn{5}{|c|}{ Farm C } \\
\hline & $N$ & Mean & SD & Min & Max & $N$ & Mean & SD & Min & Max & $N$ & Mean & SD & Min & Max \\
\hline Concentration of total bacteria ${ }^{\mathrm{a}}(\log 10 \mathrm{cfu} / \mathrm{g})$ & 9 & 8.74 & 0.47 & 8.14 & 9.38 & 12 & 8.50 & 0.31 & 8.01 & 8.89 & 12 & 8.98 & 0.41 & 8.34 & 9.78 \\
\hline Concentration of coliforms ${ }^{\mathrm{a}}(\log 10 \mathrm{cfu} / \mathrm{g})$ & 9 & 6.58 & 0.58 & 5.64 & 7.57 & 12 & 6.16 & 0.63 & 5.34 & 7.18 & 12 & 6.77 & 0.86 & 5.45 & 8.20 \\
\hline Concentration of streptococci ${ }^{\mathrm{a}}(\log 10 \mathrm{cfu} / \mathrm{g})$ & 9 & 6.70 & 0.99 & 4.30 & 7.75 & 12 & 5.83 & 0.81 & 4.48 & 7.32 & 12 & 6.85 & 0.50 & 6.18 & 7.80 \\
\hline Organic matter ${ }^{\mathrm{b}}(\%)$ & 9 & 40.56 & 5.50 & 31.00 & 47.00 & 11 & 31.18 & 3.12 & 27.00 & 37.00 & 12 & 31.92 & 7.18 & 18.00 & 41.00 \\
\hline Carbon-nitrogen ratio ${ }^{\mathrm{b}}$ & 9 & 25.56 & 2.60 & 21.00 & 30.00 & 12 & 27.17 & 10.15 & 15.00 & 43.00 & 12 & 21.83 & 6.51 & 15.00 & 33.00 \\
\hline Moisture $^{\mathrm{b}}(\%)$ & 9 & 36.78 & 3.11 & 30.00 & 40.00 & 12 & 40.75 & 6.02 & 32.00 & 50.00 & 12 & 37.08 & 9.40 & 26.00 & 58.00 \\
\hline $\mathrm{pH}^{\mathrm{b}}$ & 9 & 9.04 & 0.42 & 8.50 & 9.60 & 12 & 8.81 & 0.52 & 7.70 & 9.60 & 12 & 8.85 & 0.38 & 8.20 & 9.40 \\
\hline Wet density ${ }^{\mathrm{b}}\left(\mathrm{kg} / \mathrm{m}^{3}\right)$ & 9 & 372.67 & 46.07 & 320.00 & 460.00 & 12 & 526.17 & 39.64 & 470.00 & 596.00 & 12 & 477.33 & 103.12 & 368.00 & 690.00 \\
\hline Dry density $^{\mathrm{b}}\left(\mathrm{kg} / \mathrm{m}^{3}\right)$ & 9 & 234.67 & 21.50 & 198.00 & 276.00 & 12 & 313.17 & 48.08 & 257.00 & 402.00 & 12 & 298.42 & 91.21 & 160.00 & 496.00 \\
\hline
\end{tabular}

a Estimated from samples collected from the bedding surface.

${ }^{b}$ Estimated from composite samples of the bedding superficial and deep $(20 \mathrm{~cm})$ layers. 
random term to model repeated measurements within the $j$ th farm, and offset was the log of the number of cows included in the denominator of the incidence or prevalence calculations. For continuous outcomes, linear mixed models (Littell et al., 2006) were construced with PROC MIXED (SAS Institute, 2011) to identify predictors for each cleanliness score. Farm was considered a random effect to model the correlation between repeated observations within the same farm. Statistical analyses were performed at a significance level of 0.05 .

\section{Results}

\subsection{Missing data}

The study was interrupted 3 months before the attempted endpoint for farm $A$, due to difficulties in complying with the study protocol. On the 7 th visit to farm $\mathrm{C}$, teat swabbing and teat hygiene scoring could not be performed.

\subsection{Mastitis epidemiology}

Mean prevalence and incidence of subclinical mastitis (based on DHI SCC) during the study period were $40.9 \%$ and $20.6 \%$ for farm A, $45.7 \%$ and $10.1 \%$ for farm B, and $41.1 \%$ and $23 \%$ for farm C, respectively (Table 3 ). Mean incidence of environmental clinical mastitis was $3.0 \%, 6.4 \%$, and $2.3 \%$ for farms A, B, and C, respectively, and was not different among seasons of the year $(P=0.68)$. No interaction was found between season and farm $(P=0.12)$.

Subclinical mastitis incidence peaked at $44 \%$ during the fifth month and prevalence reached $53 \%$ on farm $A$ at the 8 th month of the study (Fig. 1). Except for the first month of the study (incidence $=7 \%$ ), farm A's incidence of environmental clinical mastitis ranged from $0 \%$ to $3 \%$ during the study period.

For farm B, no apparent increasing or decreasing trends were observed for the incidence of subclinical mastitis, which ranged from $10 \%$ to $26 \%$ during the study (Fig. 1). Prevalence of subclinical mastitis increased steadly from the 4th (36\%) to the 9th month of the study (60\%), and decreased to $40 \%$ at the end of the period. Incidence of environmental clinical mastitis ranged from $2 \%$ to $12 \%$ during the study (Fig. 1).

For farm C, decreasing trends were observed for the prevalence and incidence of subclinical mastitis during the study period (Fig. 1). Similar decreasing trends were observed for the incidences of clinical (all pathogens) and environmental clinical mastitis. None of the herds experienced outbreaks of environmental clinical mastitis during the course of the study.

Bedding moisture, carbon-nitrogen ratio, $\mathrm{pH}$, bedding age, and dry density $(P<0.01$ for all associations) were unconditionally associated with the incidence of environmental clinical mastitis (Table 4). Nonetheless, bedding moisture $(P<0.01)$ remained as a sole significant predictor in the final model (Table 5 and Fig. 2). The odds of a case of environmental clinical mastitis increased $5.7 \%$ for each one-unit increase in bedding moisture (Table 5 ).

Bedding moisture $(P<0.01)$, dry density $(P=0.04)$, and carbonnitrogen ratio $(P=0.03)$ were associated with the incidence of clinical mastitis (Table 4$)$, but moisture $(P<0.01)$ was the only predictor that remained in the final multivariable model. The odds of a case of clinical mastitis increased $5.8 \%$ for each one-unit increase in bedding moisture (Table 5 and Fig. 2).

Leg cleanliness score was the only variable associated with the prevalence and incidence of subclinical mastitis in both bivariate and multivariable analysis. The odds of a new case of subclinical mastitis (cows whose SCC shifted from $<200$ to $\geq 200$ cells/mL on 2 consecutive test days) and of a cow having SCC $>200,000$ cells $/ \mathrm{mL}$, increased $32 \%$ and $16 \%$ for each one-unit increase in leg cleanliness score, respectively (Table 5, Fig. 2).

\subsection{Profile of pathogens isolated from clinical and subclinical mas- titis cases}

Environmental pathogens were the most frequent cause of clinical mastitis on farms B (36.7\%) and C (33.8\%). E. coli was the most prevalent environmental pathogen isolated from clinical cases of farms B (8.3\%) and C (16.9\%, Table 1$)$. Contagious pathogens were the most frequent cause of clinical mastitis on farm $\mathrm{A}$ (52.2\%), and were isolated from $6.7 \%$ and $16.9 \%$ of the cases of farms B and C, respectively. Opportunistic pathogens were isolated from $2.2 \%, 11.7 \%$, and $8.5 \%$ of the clinical cases of farms $\mathrm{A}, \mathrm{B}$, and $\mathrm{C}$, respectively (Table 1 ).

Table 3

Descriptive statistics for mastitis epidemiologic indexes, bulk milk and teat swab bacterial concentrations, and cow cleanliness scores, by farm.

\begin{tabular}{|c|c|c|c|c|c|c|c|c|c|c|c|c|c|c|c|}
\hline \multirow[t]{2}{*}{ Variable } & \multicolumn{5}{|c|}{ Farm A } & \multicolumn{5}{|c|}{ Farm B } & \multicolumn{5}{|c|}{ Farm C } \\
\hline & $N$ & Mean & SD & Min & Max & $N$ & Mean & SD & Min & Max & $N$ & Mean & SD & Min & Max \\
\hline Incidence of subclinical mastitis ${ }^{\mathrm{a}}(\%)$ & 9 & 20.56 & 14.35 & 0.00 & 44.00 & 12 & 19.08 & 5.21 & 10.00 & 26.00 & 12 & 23.00 & 6.13 & 16.00 & 37.00 \\
\hline Prevalence of subclinical mastitis ${ }^{\mathrm{b}}(\%)$ & 9 & 44.68 & 6.69 & 34.21 & 53.49 & 12 & 45.72 & 6.75 & 35.71 & 60.00 & 12 & 41.13 & 8.11 & 31.00 & 59.86 \\
\hline Incidence of clinical mastitis ${ }^{\mathrm{c}}(\%)$ & 7 & 15.04 & 8.89 & 2.86 & 25.00 & 11 & 8.84 & 3.93 & 1.85 & 17.24 & 11 & 4.24 & 3.71 & 0.74 & 14.29 \\
\hline Incidence of environmental clinical mastitis (\%) & 8 & 2.95 & 1.97 & 0.00 & 7.14 & 11 & 6.36 & 3.50 & 1.85 & 12.07 & 11 & 2.33 & 2.17 & 0.00 & 8.07 \\
\hline Bulk milk concentration of total bacteria $(\log 10 \mathrm{cfu} / \mathrm{mL})$ & 9 & 3.19 & 0.53 & 2.63 & 4.36 & 12 & 3.92 & 1.43 & 1.90 & 6.40 & 12 & 3.52 & 0.52 & 2.67 & 4.63 \\
\hline Bulk milk concentration of coliforms ( $\log 10 \mathrm{cfu} / \mathrm{mL})$ & 9 & 0.00 & 0.00 & 0.00 & 0.00 & 12 & 1.95 & 1.51 & 0.00 & 4.45 & 12 & 1.45 & 0.99 & 0.00 & 2.51 \\
\hline Bulk milk concentration of streptococci $(\log 10 \mathrm{cfu} / \mathrm{mL})$ & 9 & 1.95 & 0.99 & 0.00 & 3.08 & 12 & 2.97 & 1.26 & 1.00 & 4.70 & 12 & 2.92 & 0.50 & 2.23 & 3.78 \\
\hline Teat swab concentration of total bacteria ${ }^{\mathrm{d}}(\log 10 \mathrm{cfu} / \mathrm{mL})$ & 9 & 4.69 & 0.61 & 3.59 & 5.56 & 12 & 4.43 & 0.54 & 3.38 & 5.63 & 11 & 4.74 & 0.62 & 3.49 & 5.79 \\
\hline Teat swab concentration of coliforms ${ }^{\mathrm{d}}(\log 10 \mathrm{cfu} / \mathrm{mL})$ & 9 & 1.41 & 1.51 & 0.00 & 3.83 & 12 & 0.72 & 0.83 & 0.00 & 2.40 & 11 & 0.87 & 1.10 & 0.00 & 2.62 \\
\hline Teat swab concentration of sreptococci ${ }^{\mathrm{d}}(\log 10 \mathrm{cfu} / \mathrm{mL})$ & 9 & 2.46 & 0.78 & 1.30 & 3.90 & 12 & 1.73 & 0.97 & 0.00 & 2.90 & 11 & 1.44 & 0.88 & 0.00 & 2.54 \\
\hline Udder cleanliness score ${ }^{\mathrm{e}}$ (herd weighted mean) & 9 & 1.26 & 0.18 & 1.09 & 1.61 & 12 & 1.30 & 0.17 & 1.03 & 1.59 & 12 & 1.29 & 0.27 & 1.05 & 2.04 \\
\hline Leg cleanliness score ${ }^{\mathrm{e}}$ (herd weighted mean) & 9 & 1.60 & 0.41 & 1.18 & 2.53 & 12 & 1.77 & 0.38 & 1.24 & 2.40 & 12 & 1.66 & 0.45 & 1.19 & 2.63 \\
\hline Flank cleanliness score ${ }^{\mathrm{e}}$ (herd weighted mean) & 9 & 1.36 & 0.21 & 1.10 & 1.67 & 12 & 1.43 & 0.32 & 1.03 & 2.23 & 12 & 1.40 & 0.30 & 1.10 & 2.11 \\
\hline Teat cleanliness score ${ }^{\mathrm{e}}$ (herd weighted mean) & 9 & 1.86 & 0.26 & 1.63 & 2.44 & 12 & 2.12 & 0.27 & 1.74 & 2.62 & 11 & 1.72 & 0.42 & 1.13 & 2.58 \\
\hline
\end{tabular}

\footnotetext{
a Prevalence of subclinical mastitis was defined as the percentage of cows with DHI SCC $>200,000$ cells/mL at a given test day.

${ }^{\mathrm{b}}$ Incidence of subclinical mastitis was defined as the number of cows whose SCC increased from $<200,000$ to $\geq 200,000$ cells/mL on 2 consecutive test days (cows that became infected), divided by the number of cows whose SCC was $<200,000$ cells/mL on the previous test day (cows at risk).

${ }^{\mathrm{c}}$ Incidence of clinical mastitis was defined as the number of cows who experienced mastitis during a one-month period, divided by the number of lactating cows in the herd at the DHI test day.

d Teat swabs were collected from a random sample of 30 quarters at each farm visit.

e Cleanliness scoring was performed before milking, within the CBP area, sampling $100 \%, 100 \%$, and $50 \%$ of the lactating cows of farms A, B, and C, respectively. Results were reported as weighted mean score, where weights were 1 (clean), 2 (slightly dirty), 3 (dirty), or 4 (very dirty).
} 

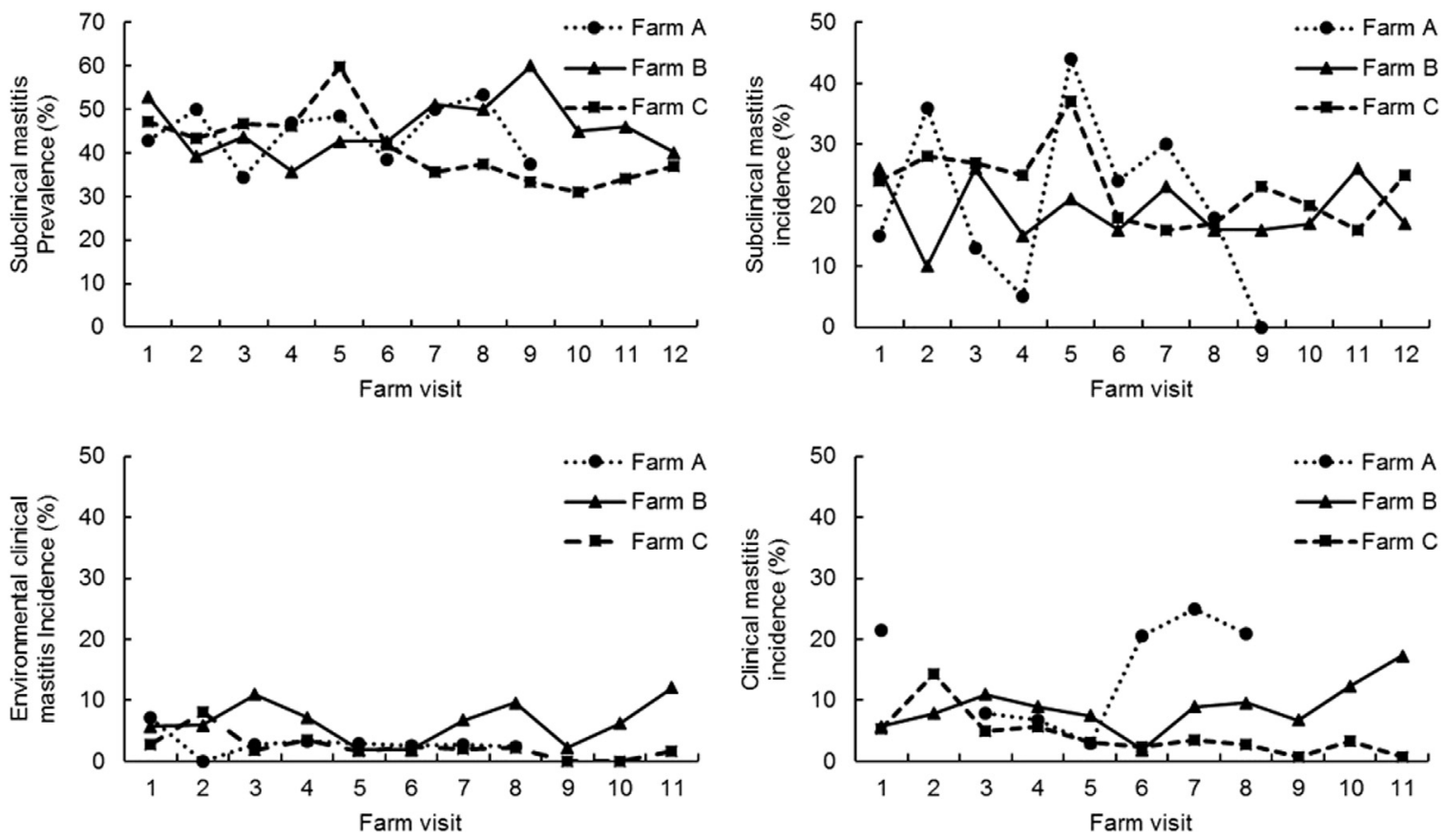

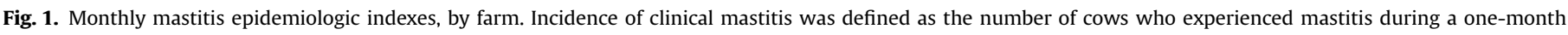

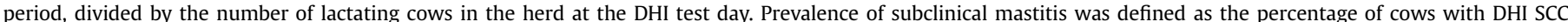

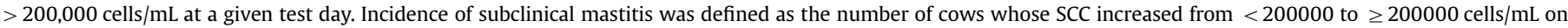
2 consecutive test days (cows that became infected), divided by the number of cows whose SCC was $<200,000$ cells/mL on the previous test day (cows at risk).

Most subclinical mastitis cases were caused by contagious pathogens (farm $A=35.2$, farm $B=20.7$, and farm $C=37.8 \%$ of all cases). $C$. bovis was the most frequent pathogen isolated from subclinical cases of farms B (17.6\%) and C (26.0\%). For farms, A, B, and $C$, environmental pathogens were isolated from $17.2 \%, 10.1 \%$, and $14.8 \%$ of all cases, and opportunistic pathogens were isolated from $7.0 \%, 10.8 \%$, and $7.6 \%$ of all cases, respectively. Farm A experienced an outbreak of $S$. agalactiae during the study, which was the most frequent pathogen isolated from clinical and subclinical mastitis cases (Table 1 ).

The prevalence of environmental pathogens that have been associated with outbreaks of untreatable mastitis, such as Nocardia spp, Pseudomonas spp, Serratia spp, and Prototheca spp was low. Only 1 case of Prototheca spp (subclinical) and 2 cases of Serratia spp (subclinical) were diagnosed during the course of the study.

Mastitis severity was recorded for 108 clinical cases with positive culture results and 46 cases with a "no growth" result. Of the 108 cases from which pathogens were isolated, the distribution of severity by pathogen group was (1) environmental $(N=35): 5.7 \%$ severe, $22.9 \%$ moderate, and $71.4 \%$ mild; (2) contagious $(N=17)$ : $0 \%$ severe, $23.5 \%$ moderate, and $76.5 \%$ mild; (3) opportunistic ( $N=10$ cases): $0 \%$ severe, $10 \%$ moderate, and $90 \%$ mild. Of the 46 cases with a "no growth" result, none were severe, $23.9 \%$ were moderate, and $76.1 \%$ were mild.

\subsection{Cow cleanliness}

For all farms, most cows remained clean (score 1) or slightly dirty (score 2) during the study period. Overall means for udder, teat, flank, and leg hygiene scores were less than 2.1 for all farms and varied little during the study (Table 3 and Fig. 3). Mean udder $(P=0.07)$, teat $(P=0.32)$, flank $(P=0.17)$, and leg $(P=0.21)$ scores were not different among seasons of the year.

Bedding wet density was unconditionally associated with leg $(P<0.04)$, teat $(P<0.01)$, and flank $(P=0.03)$ cleanliness, and bedding dry density was positively associated with udder
$(P=0.02)$ and teat $(P=0.02)$ cleanliness. Bedding organic matter was negatively associated with teat $(P=0.03)$ and flank $(P=0.04)$ cleanliness. Mean udder cleanliness increased across bedding age categories $(P<0.01$, Table 4$)$.

Bedding wet density remained as a sole predictor of all cleanliness scores studied (Table 4). All associations were positive, but of small magnitude (Table 5 and Fig. 4). None of the bedding variables studied were associated with teat skin concentration of total bacteria, streptococci, or coliforms.

\subsection{Bulk tank milk bacterial concentrations}

For farms A and C, bulk milk concentration of total bacteria ranged from 2.6 to $4.6 \log 10 \mathrm{cfu} / \mathrm{mL}$ and remained below the Brazilian legal limit $\left(3 \times 10^{5} \mathrm{cfu} / \mathrm{mL}\right)$ during the entire study period (Fig. 5). For farm B, bulk milk concentration of total bacteria increased steadly from the fourth month (1.9) and reached $6.4 \log 10 \mathrm{cfu} / \mathrm{mL}$ at the sixth month of the study. Subsequently, bulk milk concentration of total bacteria decreased to levels similar to those observed at the beginning of the study. A total of 2 monthly counts were greater than the official regulatory limit (Fig. 5).

Longitudinal trends of bulk milk concentration of streptococci were similar to those observed for total bacteria (Fig. 5). Trends of bulk milk concentration of coliforms were similar for farms B and $\mathrm{C}$, and showed great variability during the study (Fig. 5). Farm A's bulk milk concentration of coliforms was below the detection limit of the culturing method throughout the study. Bulk milk concentrations of total bacteria $(P=0.36)$, streptococci $(P=0.12)$, and coliforms $(P=0.91)$ were not different among seasons of the year.

Bedding dry density $(P<0.01)$, wet density $(P=0.02)$ and organic matter $(P=0.02)$ were unconditionally associated with bulk milk concentration of total bacteria, but only wet density remained in the final model (positive association, Table 5). Bedding dry density was the only variable associated (positive association) with bulk milk concentration of streptococci $(P=0.02)$ and organic 
Table 4

Unconditional associations $(P<0.05)$ between explanatory variables and study outcomes.

\begin{tabular}{llll}
\hline Outcome (bold letters) and explanatory variables & Coefficient & SE & P-value \\
\hline Incidence of clinical mastitis - environmental pathogens & & & \\
Bedding moisture (\%) & 0.055 & 0.013 & $<0.01$ \\
Bedding dry density $\left(\mathrm{kg} / \mathrm{m}^{3}\right)$ & -0.006 & 0.002 & $<0.01$ \\
Bedding carbon-nitrogen ratio & 0.050 & 0.014 & $<0.01$ \\
Bedding pH & -0.948 & 0.332 & $<0.01$ \\
Bedding age (months) & & & 0.01 \\
$\leq 4$ & 0.869 & 0.273 & \\
$5-8$ & 0.271 & 0.308 & \\
$\geq 9$ & Reference & &
\end{tabular}

infected), divided by the number of cows whose SCC was $<200,000$ cells $/ \mathrm{mL}$ on the previous test day (cows at risk).

d Associations were derived from linear mixed models based on a normal distribution. Cleanliness scoring was performed before milking, within the CBP area, sampling $100 \%, 100 \%$, and $50 \%$ of the lactating cows of farms $\mathrm{A}, \mathrm{B}$, and $\mathrm{C}$, respectively. Results were reported as weighted mean score, where weights were 1 (clean), 2 (slightly dirty), 3 (dirty), or 4 (very dirty).

e Associations were derived from linear mixed models based on a normal distribution.

matter was the sole predictor (negative association) for the concentration of coliforms $(P=0.049$, Table 5$)$.

\section{Discussion}

Results of this study provide novel information on biosecurity and management of milk quality in CBP systems. By monitoring 3 herds during the course of the study, we did not observe outbreaks of environmental subclinical or clinical mastitis, nor a concerning prevalence of IMI caused by environmental pathogens that are refractory to conventional treatments (such as Nocardia spp and Prototheca spp), which have been suspected to be prevalent in this unique organic environment. The identification of compost bedding factors associated with mastitis epidemiologic indexes, cow cleanliness, and microbial quality of bulk tank milk, such as density and moisture, supports the hypothesis that changes in bedding characteristics can affect the occurrence of environmental mastitis and the quality of milk produced in CBP systems.

Because of the high bacterial concentrations found in compost bedding (Barberg et al. 2007a, 2007b; Black et al., 2014), researchers have recommended adoption of excellent pre-milking hygienic procedures, and that bedding be maintained dry and not adherent to cows (Barberg et al. 2007a, 2007b; Black et al., 2013). Nonetheless, these associations had not been scientifically demonstrated. Results of the present study indicate that bedding factors such as density and moisture are associated with mastitis epidemiologic indexes and cow cleanliness. Wet density is related to particle size and moisture. As particle size decreases and moisture increases, bedding becomes denser and more compacted.

Another consequence of denser bedding is the decrease in bedding aeration. An aerobic composting process is important to maintain an efficient microbiological decomposition of the organic material. When bedding is loose and aerated, temperature in the deep layer (20 cm deep) increases to approximately $40-55^{\circ} \mathrm{C}$ as a consequence of microbial activity (Barberg et al. 2007a, 2007b; Black et al., 2014). Thus, a combination of effective aeration and high deep layer temperature facilitates moisture loss and maintenance of a dry environment to cows.

In the present study, bedding moisture was the main predictor for the incidence of environmental clinical mastitis. Bedding moisture has been reported as one of most difficult characteristics to control in CBP systems (Lobeck et al., 2011) because it can be influenced by bedding management and weather conditions. Inadequate aeration, high animal density, and lack of ventilation can lead to increased moisture levels (Janni et al., 2007; Black et al., 2014). Weather factors include air humidity and rainwater entering the $\mathrm{CBP}$.

There could be different mechanisms by which bedding moisture is associated with increased risk of environmental mastitis. Moisture is essential for bacterial growth and increase in moisture levels can favor multiplication of microorganisms and therefore increase exposure to cows. Another factor that needs to be studied is the transfer of bacteria to the teat skin. It can be 
Table 5

Associations between explanatory variables and study outcomes derived from multivariable analyses.

\begin{tabular}{|c|c|c|c|}
\hline Outcome (bold letters) and explanatory variables & Coefficient & SE & $P$-value \\
\hline \multicolumn{4}{|c|}{ Incidence of clinical mastitis - environmental pathogens ${ }^{a}$} \\
\hline Intercept & -5.457 & 0.638 & \\
\hline Bedding moisture (\%) & 0.055 & 0.013 & $<0.01$ \\
\hline \multicolumn{4}{|l|}{ Incidence of clinical mastitis - all pathogens ${ }^{a}$} \\
\hline Intercept & -4.596 & 0.635 & \\
\hline Bedding moisture (\%) & 0.056 & 0.010 & $<0.01$ \\
\hline \multicolumn{4}{|l|}{ Prevalence of subclinical mastitis ${ }^{\mathrm{b}}$} \\
\hline Intercept & -1.101 & 0.126 & \\
\hline Leg cleanliness score (herd weighted mean) & 0.148 & 0.071 & 0.04 \\
\hline \multicolumn{4}{|l|}{ Incidence of subclinical mastitis ${ }^{\mathrm{c}}$} \\
\hline Intercept & -2.004 & 0.232 & \\
\hline Leg cleanliness score (herd weighted mean) & 0.279 & 0.129 & 0.04 \\
\hline \multicolumn{4}{|l|}{ Udder cleanliness score $^{d}$} \\
\hline Intercept & 1.40 & 0.67 & \\
\hline Bedding wet density $\left(\mathrm{kg} / \mathrm{m}^{3}\right)$ & 0.002 & 0.001 & 0.74 \\
\hline Wet density $\times$ Farm & & & $<0.01$ \\
\hline Farm A & 0.001 & 0.002 & \\
\hline Farm C & 0.004 & 0.001 & \\
\hline Farm B & Reference & & \\
\hline \multicolumn{4}{|l|}{ Teat cleanliness score $^{d}$} \\
\hline Intercept & 0.89 & 0.34 & \\
\hline Bedding wet density $\left(\mathrm{kg} / \mathrm{m}^{3}\right)$ & 0.002 & 0.001 & $<0.01$ \\
\hline \multicolumn{4}{|l|}{ Flank cleanliness score ${ }^{\mathrm{d}}$} \\
\hline Intercept & 0.87 & 0.24 & \\
\hline Bedding wet density $\left(\mathrm{kg} / \mathrm{m}^{3}\right)$ & 0.001 & 0.001 & 0.03 \\
\hline \multicolumn{4}{|l|}{ Leg cleanliness score ${ }^{d}$} \\
\hline Intercept & 0.95 & 0.35 & \\
\hline Bedding wet density $\left(\mathrm{kg} / \mathrm{m}^{3}\right)$ & 0.002 & 0.001 & 0.04 \\
\hline \multicolumn{4}{|l|}{ Bulk tank milk - concentration of total bacteria ${ }^{e}$} \\
\hline Intercept & 1.53 & 0.82 & \\
\hline Bedding wet density $\left(\mathrm{kg} / \mathrm{m}^{3}\right)$ & 0.004 & 0.002 & 0.02 \\
\hline \multicolumn{4}{|l|}{ Bulk tank milk - concentration of streptococci ${ }^{\mathrm{e}}$} \\
\hline Intercept & 0.96 & 0.73 & \\
\hline Bedding dry density $\left(\mathrm{kg} / \mathrm{m}^{3}\right)$ & 0.006 & 0.25 & 0.02 \\
\hline \multicolumn{4}{|l|}{ Bulk tank milk - concentration of coliforms ${ }^{\mathrm{e}}$} \\
\hline Intercept & 3.55 & 1.22 & \\
\hline Bedding organic matter (\%) & -0.07 & 0.03 & 0.04 \\
\hline
\end{tabular}

a Associations were derived from generalized linear mixed models based on a binomial distribution. Model coefficients are log (odds ratio). Incidence of clinical mastitis was defined as the number of cows who experienced mastitis during a one-month period, divided by the number of lactating cows in the herd at the DHI test day.

${ }^{\mathrm{b}}$ Associations were derived from generalized linear mixed models based on a negative binomial distribution. Model coefficients are log (risk ratio). Prevalence of subclinical mastitis was defined as the percentage of cows with DHI SCC $>200000$ cells/mL at a given test day.

${ }^{c}$ Associations were derived from generalized linear mixed models based on a negative binomial distribution. Model coefficients are log (risk ratio). Incidence of subclinical mastitis was defined as the number of cows whose SCC increased from $<200,000$ to $\geq 200,000$ cells $/ \mathrm{mL}$ on 2 consecutive test days (cows that became infected), divided by the number of cows whose SCC was $<200,000$ cells/mL on the previous test day (cows at risk).

${ }^{\mathrm{d}}$ Associations were derived from linear mixed models based on a normal distribution. Cleanliness scoring was performed before milking, within the CBP area, sampling $100 \%, 100 \%$, and $50 \%$ of the lactating cows of farms A, B, and C, respectively. Results were reported as weighted mean score, where weights were 1 (clean), 2 (slightly dirty), 3 (dirty), or 4 (very dirty).

Associations were derived from linear mixed models based on a normal distribution

hypothesized that smaller (denser bedding) and moisten bedding particles adhere to cows and facilitate the transfer of bacteria to the skin. Bedding wet density was positively associated with all cleanliness scores studied here. Conversely, if bedding is maintained dry and loose, transferring of bacteria to the skin may be minimized. Further research should be conducted to study physical characteristics of bedding particles (such as particle size and water retention) that can affect the transfer of bacteria to the teat skin.

It was interesting to observe that bedding moisture decreased dramatically on farm $\mathrm{C}$ after installation of fans over the bedding area (Favero et al., 2015). The bedding became dry and not adherent to cows, which remained in excellent hygienic conditions. Even after reaching moisture levels as low as $30 \%$, bedding deep temperature $\left(20 \mathrm{~cm}\right.$ deep) was maintained $>40{ }^{\circ} \mathrm{C}$, indicating that it is possible to maintain dry bedding without compromising microbiological activity.

A negative association was found between bedding $\mathrm{pH}$ and the incidence of environmental clinical mastitis. It has been consistently demonstrated that, during the composting process, $\mathrm{pH}$ increases with time. Perhaps the alkaline $\mathrm{pH}$ levels found in this study (overall mean $>8.8$ for all farms) inhibit growth of environmental mastitis pathogens. The effect of $\mathrm{pH}$ on bedding bacterial populations needs to be further studied because it could be managed on the farms.

Aging of the composting process results in changes such as decrease in both density and organic matter, and increase in the water retention capacity of the material (Kiehl, 1985). As a result of the bivariate analysis, we observed that the risk of environmental mastitis decreased progressively as bedding became older. This changes could be explained by some characteristics of new bedding material such as high moisture content, organic matter, and carbon-nitrogen ratio (Favero et al., 2015). Thus, the ideal time of bedding total replacement needs to be studied because it may influence the risk of mastitis.

The distribution of environmental pathogens isolated from clinical and subclinical mastitis cases was similar to those reported from different countries and housing systems (Olde Riekerink et al., 2008; Jobim et al., 2010; Lago et al., 2011; Oliveira and Ruegg, 2014). In agreement with those studies, "no growth" was the most frequent culture result (33.3\% of all cases), and E. coli (9.6\%) and environmental streptococci ( $17.5 \%$ of all cases) were the most frequent pathogens isolated from clinical mastitis cases.

The distribution of pathogens isolated from subclinical mastitis was characterized by a high prevalence of contagious pathogens. $C$. bovis, $S$. agalactiae, and $S$. aureus are still highly prevalent on Brazilian dairies (Bueno et al., 2008) due to the lack of adoption of mastitis control programs. Except for contagious pathogens, coagulase-negative staphylococci and environmental streptococci were the most prevalent pathogens isolated form subclinical mastitis cases, as previously reported (Gianneechini et al., 2002; Wallace et al., 2004; Pol and Ruegg, 2007).

Cow cleanliness have been associated with milk quality outcomes at the cow (prevalence of mastitis; Schreiner and Ruegg, 2003) and herd (bulk tank milk SCC; Barkema et al., 1998; Ellis et al., 2007; Dufour et al., 2011) levels. Results of the present study corroborate with those of North American studies that have demonstrated that cows housed in the CBP are maintained in good hygienic conditions, comparable to standard systems such as well managed sand-bedded freestalls (Lobeck et al., 2011). Mean cow cleanliness score (ranging from $1=$ clean to $5=$ very dirty) was 2.6 (Barberg et al. 2007a, 2007b) e 3.1 (Shane et al., 2010) for a population of Minnesota CBP. Likewise, Black et al. (2013) reported mean cleanliness score of 2.2 (scale ranging from $1=$ clean to $4=$ very dirty) for a group of Kentucky CBP. Researchers found significant seasonal variation and reported difficulties controlling cow cleanliness during humid and rainy weather. In Brazilian conditions, where weather differences among seasons are not as extreme as in North America, cows remained in excellent hygienic conditions throughout the year studied. Housing cows in wellmanaged $\mathrm{CBP}$ could be an interesting alternative to one of the most prevalent systems worldwide, the semi-confinement (dry lot), in which cows are usually maintained in poor hygienic 

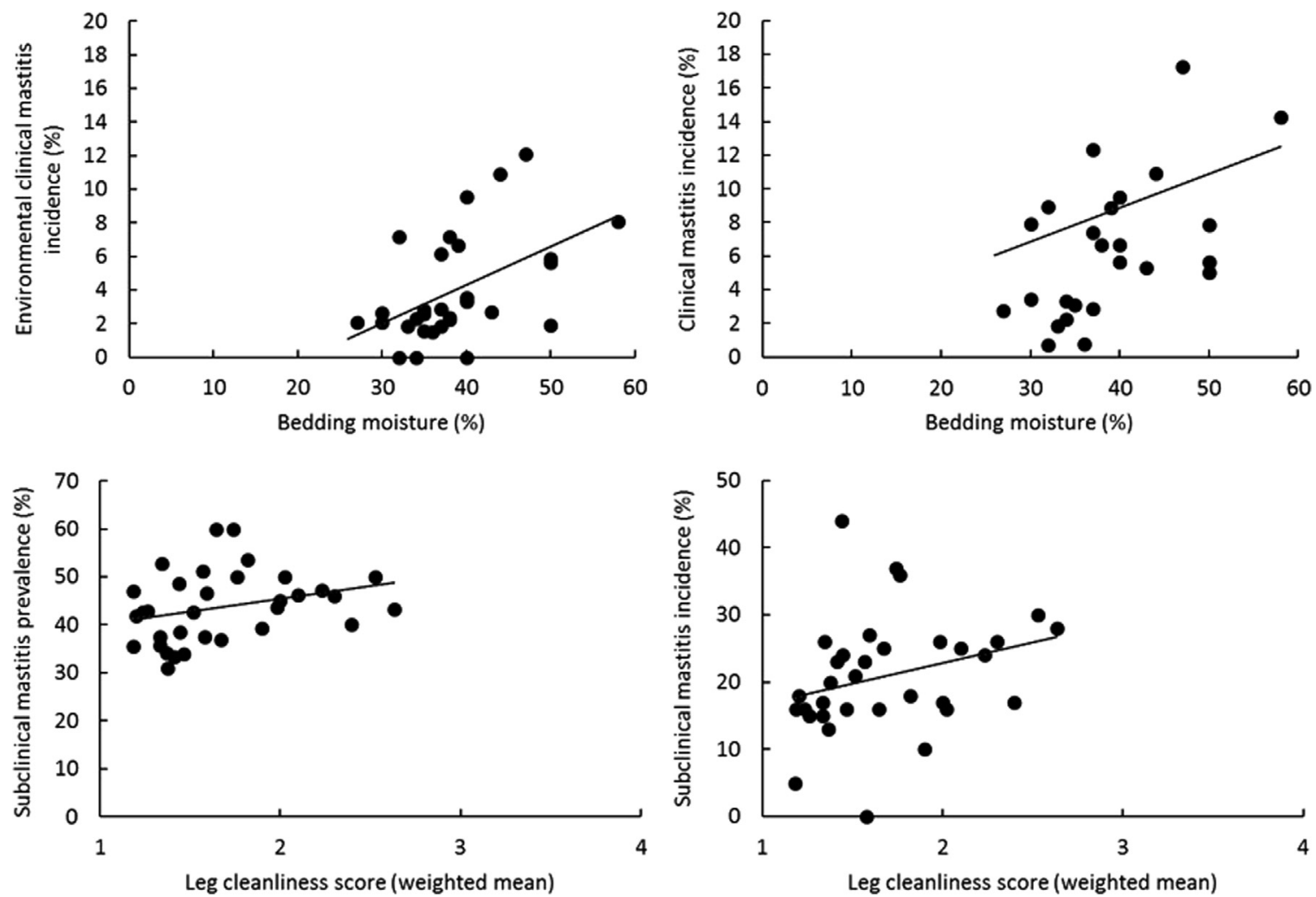

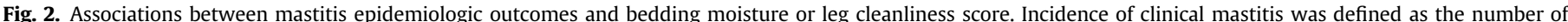

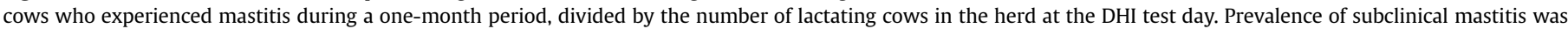

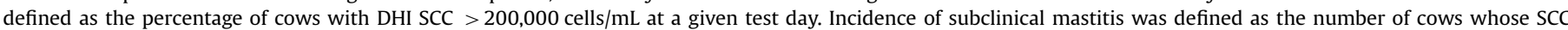

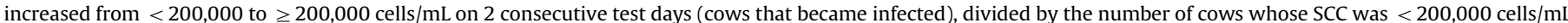

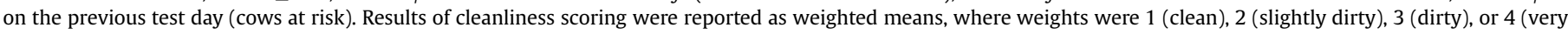
dirty).

conditions.
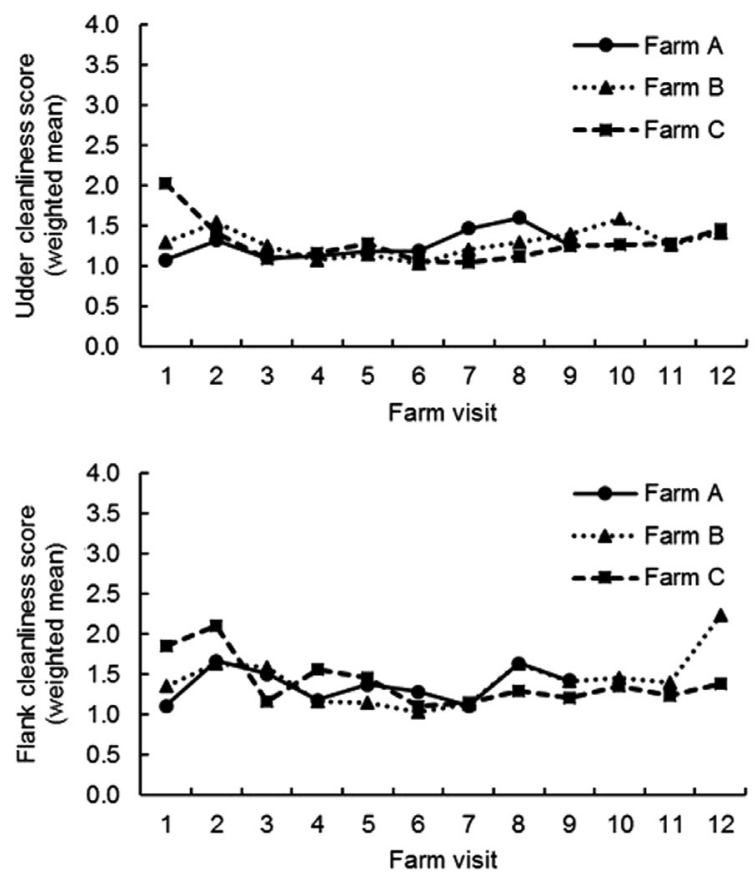

\subsection{Study limitations}

One limitation of this study was the high prevalence of
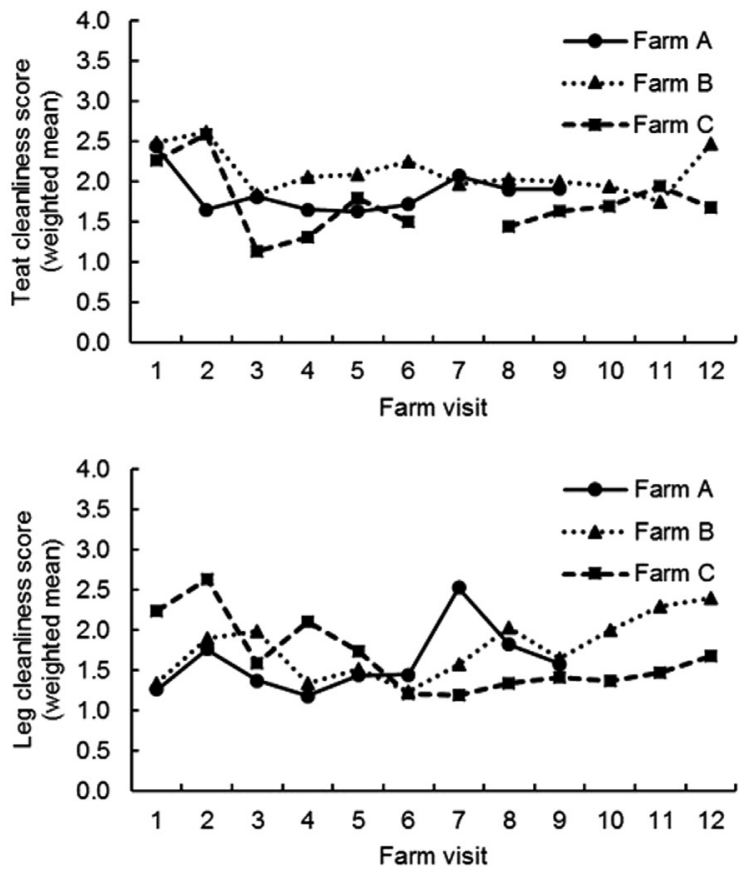

Fig. 3. Monthly udder, teat, flank and leg cleanliness scores, by farm. Cleanliness scoring was performed before milking, within the CBP area, sampling $100 \%, 100 \%$, and $50 \%$ of the lactating cows of farms A, B, and C, respectively. Results were reported as weighted mean score, where weights were 1 (clean), 2 (slightly dirty), 3 (dirty), or 4 (very dirty). 

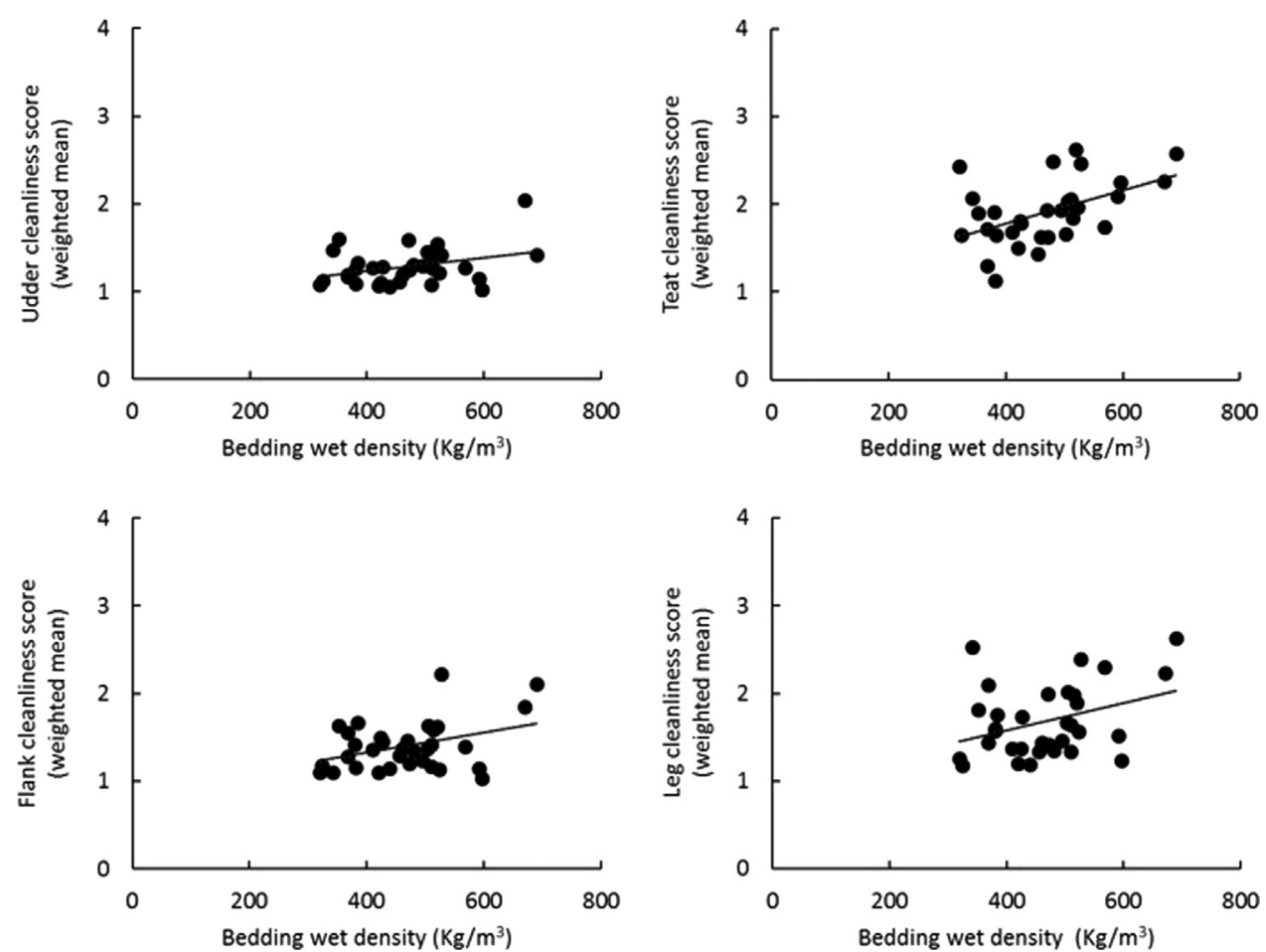

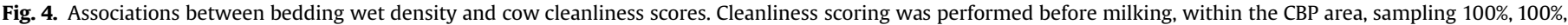

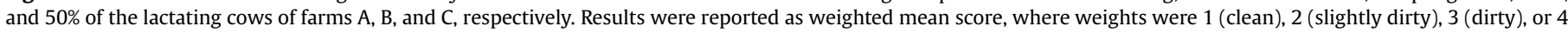
(very dirty). Wet density was estimated using composite bedding samples from 12 areas of the CBP, collected from the surface and deep (20 cm) layers.

contagious pathogens observed in the herds studied, which probably resulted in difficulties to separate the effect of bedding characteristics on the occurrence of subclinical mastitis (defined based on SCC). If possible, selecting herds where contagions pathogens have been controlled will be important for future studies.

It is important to emphasize that the present study was not designed to assess whether shifting from other systems to the CBP would improve milk quality and mastitis control. Thus, longitudinal trends in mastitis epidemiologic indexes observed on the 3 farms could have been affected by several factors not related to compost bedding, such as milking machine, milking management, and profile of pathogens found on each herd. Moreover,
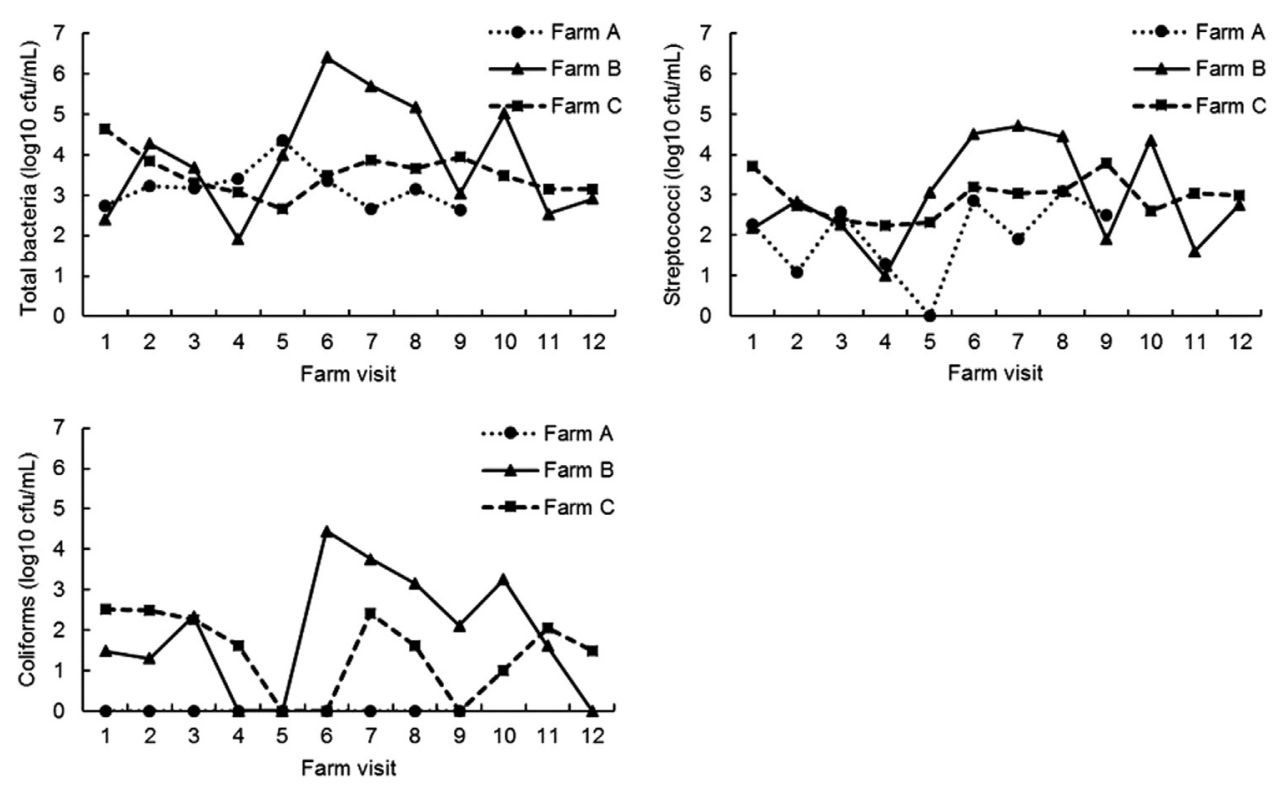

Fig. 5. Monthly bulk milk concentration of total bacteria, streptococci, and coliforms by farm. here.

because bedding materials were different among farms, assessment of the effect of bedding type (e.g., sawdust versus peanut shell) on mastitis epidemiologic indexes or animal hygiene should not be encouraged because one farm might not be representative of a greater population of farms that use the same bedding type. Likewise, comparison of pathogen profiles, mastitis epidemiologic indexes, and bedding characteristics among the 3 farms cannot answer relevant scientific questions because biological differences cannot be explained when derived from the study design used 


\section{Conclusions}

Results of this study suggest that changes in compost bedding characteristics such as density and moisture can affect the occurrence of environmental clinical mastitis, cow cleanliness, and microbial quality of milk produced in CBP systems. Managing bedding to remain dry and loose will result in cleaner animals with decreased risk of mastitis. Cow cleanliness scoring can be useful to aid bedding management and asses the risk of subclinical mastitis.

Coliforms and environmental streptococci were the most frequent environmental pathogens isolated from clinical mastitis cases. The prevalence of IMI caused by Nocardia spp, yeast, Prototheca spp, Serratia spp, Pseudomonas spp, and other environmental pathogens that can cause outbreaks of untreatable mastitis was not concerning. No outbreaks of environmental mastitis were observed during the course of the study.

\section{Conflict of interest statement}

None.

\section{Acknowledgments}

We are thankful to Dr. Leonardo Dantas and the farmers and collaborators who cooperated with the study. This research was funded by the São Paulo Research Foundation (FAPESP), Grant 2013/00517-3.

\section{References}

Astiz, S., Sebastian, F., Fargas, O., Fernández, M., Calvet, E., 2014. Enhanced udder health and milk yield of dairy cattle on compost bedding systems during the dry period: a comparative study. Livest. Sci. 159, 161-164.

Barberg, A.E., Endres, M.I., Janni, K., 2007a. Compost dairy barns in Minnesota: a descriptive study. Appl. Eng. Agric. 23, 231-238.

Barberg, A.E., Endres, M.I., Salfer, J.A., Reneau, J.K., 2007b. Performance and welfare of dairy cows in an alternative housing system in Minnesota. J. Dairy Sci. 90, 1575-1583.

Barkema, H.W., Schukken, Y.H., Lam, T.J., Beiboer, M.L., Benedictus, G., Brand, A., 1998. Management practices associated with low, medium, and high somatic cell counts in bulk milk. J. Dairy Sci. 81, 1917-1927.

Black, R.A., Taraba, J.L., Day, G.B., Damasceno, F.A., Bewley, J.M., 2013. Compost bedded pack dairy barn management, performance, and producer satisfaction. J. Dairy Sci. 96, 8060-8074.

Black, R.A., Taraba, J., Day, G., Damasceno, F., Newman, M., Akers, K.A., Wood, C.L., McQuerry, K.J., Bewley, J.M., 2014. The relationship between compost bedded pack performance, management, and bacterial counts. J. Dairy Sci. 97. 2669-2679.

Bueno, V.F.F., Nicolau, E.S., Mesquita, A.J., Ribeiro, A.R., Silva, J.A.B., Costa, E.O., Couto, D.V., 2008. Etiologia e suscetibilidade à antimicrobianos dos agentes da mastite bovina isolados na região de Pirassununga-SP-Brasil. Rev. Patol. Trop. 32, 33-43.

Condas, L.A., Ribeiro, M.G., Yazawa, K., Vargas, A.P.C., Salerno, T., Giuffrida, R., Langoni, H., Melville, P.A., Biesdorf, S., Matsuzawa, T., Gonoi, T., Kastelic, J.P., Barkema, H.W., 2013. Molecular identification and antimicrobial susceptibility of Nocardia spp. isolated from bovine mastitis in Brazil. Vet. Microbiol. 167,
$708-712$.

Dufour, S., Fréchette, A., Barkema, H.W., Mussell, A., Scholl, D.T., 2011. Invited review: effect of udder health management practices on herd somatic cell count J. Dairy Sci. 94, 563-579.

Ellis, K.A., Innocent, G.T., Mihm, M., Cripps, P., McLean, W.G., Howard, C.V., GroveWhite, D., 2007. Dairy cow cleanliness and milk quality on organic and conventional farms in the UK. J. Dairy Res. 74, 302-310.

Favero, S., Portilho, F.V.R., Oliveira, A.C.R., Langoni, H., Pantoja, J.C.F., 2015. Longitudinal trends and associations between compost bedding characteristics and bedding bacterial concentrations. J. Agric. Sci., 7, in press.

Gianneechini, R., Concha, C., Rivero, Delucci, R.,I., Moreno López, J., 2002. Occurrence of clinical and sub-clinical mastitis in dairy herds in the west littoral region in Uruguay. Acta Vet. Scand. 43, 221-230.

Janni, K., Endres, M., Reneau, J., Schoper, W., 2007. Compost dairy barn layout and management recommendations. Appl. Eng. Agric. 23, 97-102.

Janosi, S., Ratz, F., Szigeti, G., Kulcsar, M., Kerenyi, J., Lauko, T., Huszenicza, G., 2001. Review of the microbiological, pathological, and clinical aspects of bovine mastitis caused by the alga Prototheca zopfii. Vet. Q. 23, 58-61.

Jobim, M.B., Lopes, M.A., Costa, G.M.D., Demeu, F.A., 2010. Pathogens associated with bovine mastitis in dairy herds in the south region of Brazil. Bol. Ind. Anim. 67, 175-181.

Kiehl, E.J., 1985. Compostagem. Pages 229-310 in Fertilizantes orgânicos. Agronômica Ceres, Piracicaba, Brasil.

Lago, A., Godden, S.M., Bey, R., Ruegg, P.L., Leslie, K., 2011. The selective treatment of clinical mastitis based on on-farm culture results: I. Effects on antibiotic use, milk withholding time, and short-term clinical and bacteriological outcomes. J. Dairy Sci. 94, 4441-4456.

Littell, R., Milliken, G., Stroup, W., Wolfinger, R., Schabenberger, O., 2006. SAS for mixed models, 2nd ed. SAS institute Inc, Cary, NC.

Lobeck, K.M., Endres, M.I., Shane, E.M., Godden, S.M., Fetrow, J., 2011. Animal welfare in cross-ventilated, compost-bedded pack, and naturally ventilated dairy barns in the upper Midwest. J. Dairy Sci. 94, 5469-5479.

Lobeck, K., Endres, M., Janni, K., Godden, S., Fetrow, J., 2012. Environmental characteristics and bacterial counts in bedding and milk bulk tank of low profile cross-ventilated, naturally ventilated, and compost bedded pack dairy barns. Appl. Eng. Agric. 28, 117-128.

NMC (National Mastitis Council), 1999. Laboratory Handbook on Bovine Mastitis. National Mastitis Council, Madison, WI, USA.

Olde Riekerink, R.G.M., Barkema, H.W., Kelton, D.F., Scholl, D.T., 2008. Incidence rate of clinical mastitis on Canadian dairy farms. J. Dairy Sci. 91, 1366-1377.

Oliveira, L., Ruegg, P.L., 2014. Treatments of clinical mastitis occurring in cows on 51 large dairy herds in Wisconsin. J. Dairy Sci. 97, 5426-5436.

Palta, M., 2003. Quantitative Methods on Population Health: Extensions of Ordinary Regression. John Wiley and Sons, Hoboken, NJ, USA.

Pol, M., Ruegg, P.L., 2007. Treatment practices and quantification of antimicrobial drug usage in conventional and organic dairy farms in Wisconsin. J. Dairy Sci. 90, 249-261.

SAS Institute, 2011. SAS/STAT User's Guide. Version 9.3. SAS Institute Inc., Cary, NC. Schreiner, D.A., Ruegg, P.L., 2003. Relationship between udder and leg hygiene scores and subclinical mastitis. J. Dairy Sci. 86, 3460-3465.

Shane, E., Endres, M., Janni, K., 2010. Alternative bedding materials for compost bedded pack barns in Minnesota: a descriptive study. Appl. Eng. Agric. 26, 465-473.

Svennesen, L., Enevoldsen, C., Bjerg, B., Klaas, I.C., 2014. Udder health in a Danish compost bedded pack barn. Page 154 in National Mastitis Council Regional Meeting Proceedings. Ghent, Belgium. Natl. Mastitis Counc. Inc, Madison, WI, USA.

Wallace, J.A., Stipetic, K., Schukken, Y.H., Dingwell, R.T., Baillargeon, P., Bacic, G., Leslie, K.E., 2004. An evaluation of a treatment protocol for intramammary infections in early postpartum of dairy cows based on a positive california mastitis test result. Bovine Pract. 38, 72-78.

Wenz, J.R., Barrington, G.M., Garry, F.B., Dinsmore, R.P., Callan, R.J., 2001. Use of systemic disease signs to assess disease severity in dairy cows with acute coliform mastitis. J. Am. Vet. Med. Assoc. 218, 567-572.

Zdanowicz, M., Shelford, J., Tucker, C., Weary, D., Von Keyserlingk, M., 2004. Bacterial populations on teat ends of dairy cows housed in free stalls and bedded with either sand or sawdust. J. Dairy Sci. 87, 1694-1701. 